\title{
Antonino Leonelli, Fermo posta. Paradiso Modena 2007, wyd. Tipo-Litografia Paltrinieri, s. 264
}

Jedną z cech człowieka mądrego i dojrzałego jest zdolność dokonywania wnikliwej obserwacji, a także idącej w ślad za tym refleksji. „Skłonność” ta - jak pokazuje doświadczenie - w miarę upływu lat staje się coraz bardziej widoczna. Tę „prawidłowość” życiową widać wyraźnie w ostatniej książce ks. prał. dr. Antonino Leonelli z Modeny (Włochy) zatytułowanej: Fermo posta. Paradiso. Dzieło to, wydane w czerwcu 2007 roku w Modenie (Włochy) nakładem miejscowego wydawnictwa Tipo-Litografia Paltrinieri, otrzymałem od Autora w Cortinie d’Ampezzo latem 2008.

W książce Fermo posta. Paradiso ks. Antonino Leonelli usiłuje jeszcze raz spojrzeć na swoje życie, ale już w perspektywie przyszłości. Okazją ku temu stała się 60 rocznica święceń kapłańskich (wyświęcony w 1947 r.). Zapewne tym też należy tłumaczyć tak wymowny tytuł jego ostatniego dzieła - jak sam wielokrotnie zaznaczał - oraz rysunek słynnego grafika Gustawa Doré (1832-1883) umieszczony na pierwszej stronie okładki. Jest to ilustracja do XXVII rozdziału Raju Dantego, ukazująca niezliczone chóry aniołów w geście uwielbienia.

Autor książki Fermo posta Paradiso urodził się w Modenie (Włochy) 3 maja 1924 roku. Po zdobyciu wiedzy w zakresie szkoły średniej, w dniu 18 września 1943 roku przekroczył progi Wyższego Seminarium Duchownego w Modenie. Po czterech latach studiów 22 czerwca 1947 roku otrzymał święcenia kapłańskie z rąk ks. abp. Cesare Boccoleri (1875-1956), ordynariusza Modeny (1940-1956). Początkowo pracował jako wikariusz w parafii Campogalliano, a następnie w parafii katedralnej w Modenie. W 1953 roku na Uniwersytecie w Modenie obronił doktorat z zakresu prawoznawstwa. W latach 1950-1957 wykładał religioznawstwo i filozofię w Instytucie Pedagogicznym Sióstr Urszulanek w Modenie. Od 1961 do 1985 roku piastował urząd dyrektora szkół średnich. Następnie został mianowany dyrektorem Instytutu Diecezjalnego im. Jana kard. Morone (1520-1580). W międzyczasie został zaliczony do grona różnych stowarzyszeń i towarzystw naukowych. Działalność pedagogiczno-dydaktyczną zakończył oficjalnie w 1990 roku, poświęcając resztę życia posłudze kapłańskiej i badaniom historycznym. Ksiądz Antonino Leonelli opublikował wiele z dzieł z zakresu: historii Kościoła lokalnego (Storia di Moderici, Storia di Bolognia, Il prete delle mute, Don Severino Fabriani, La storia della diocesi di Modena), katechezy (Le venti lezioni di Religione nella scuola elementare), a także szereg pozycji z dziedziny ascetyki (Carissima Betty, Ciò che manca ad Adamo, L'esame di maturità, „Ragazzi 
come tè, Le labbra del profeta, L'armatura di Dio, Il breviario delle vacanze, Entrando in classe, Tutto comincia da un se..., La via della Perfezione).

Świadom przemijalności życia, ks. Antonino Leonelli potraktował swoją książkę jako rodzaj pożegnania ze znajomymi i z całym światem. Gotowy na „ostatnie wezwanie” - jak to wyraźnie zaznaczył we Wstępie (s. 3) - wspomina szereg epizodów z minionego życia i stara się niejako rozliczyć się z nim. Uczynił to $\mathrm{w}$ sposób bardzo wyrafinowany i z dużym doświadczeniem pisarskim, o czym świadczy jego wcześniejszy dorobek o charakterze autobiograficznym i pamiętnikarskim opublikowany w serii: „I pensieri di Dio. Scritti autobiografici", a mianowicie: Carissima Betty - 1990; Il salterio della nonna Nina - 1993; Se torno a nascere..." - 1994; Dodici sporte di avanzi - 1997; Sono Fausto! - 2004.

Określając rodzaj literacki książki ks. Leonelli, należy stwierdzić, iż jest to zbiór wielu listów napisanych pod koniec życia do znanych postaci, o których Autor jest przekonany, że spotka ich w niebie. Stąd też traktuje on swoją książkę jako przesyłkę wysłaną do nieba $\mathrm{w}$ formie poste restante (po włosku fermo posta), aby otrzymać dobre słowo $\mathrm{z}$ ich strony, kiedy zapuka do bram wieczności (s. 262). Z właściwą sobie delikatnością Autor mówi we Wstępie (s. 3), że dzieło to traktuje jako wspomnienie skierowane do krewnych i przyjaciół z nadzieję, iż zostanie ono przyjęte jako jego testament (może troszeczkę za długi).

Wierny swemu postanowieniu ks. Antonino Leonelli zebrał w książce Fermo posta. Paradiso aż 67 listów, które zaadresował do różnych postaci znanych mu z Biblii, autopsji, a także z lektury dzieł teologicznych i literackich. Każdy list zawiera ogólny temat, który w bezpośredni sposób nawiązuje do adresata. „Niebieską korespondencję" ks. Antonino otwierają listy skierowane do jego rodziców: trzy do ojca, którego nazywa ojczulkiem (Babbo) oraz jeden do matki. Pierwsze listy zawierają różne szczegóły z życia, wyłowione z pamięci po 50 latach, jakie upłynęły od śmierci ojca. Autor traktuje je jako wielką powinność, ponieważ dotychczas pomijał postać ojca w swoich wspomnieniach. Szczególnie wzruszający jest fragmentu testamentu sporządzony przez ojca 13 czerwca 1944 roku podczas amerykańskiego nalotu na Modenę. List do matki Guglielminy (zwana w rodzinie: Mina) nosi wymowny tytuł: Una mina e nove mine (tłum. Jedna Mina i dziewięć talentów - po włosku: „Min”)”. Z dzisiejszej perspektywy ks. Leonelli patrzy na życie swojej matki oczyma teologa i biblisty. Traktuje je jako komentarz do Jezusowej przypowieści o gospodarzu, który powierzył 10 sługom po jednym talencie (Łk 19,19). Jego mama pomnożyła otrzymany talent dziewięciokrotnie. Szkoda, że nie dziesięciokrotnie - jak zwykł powtarzać.

Największy zbiór stanowią listy zaadresowane do różnych postaci biblijnych (23): nieuczciwego zarządcy (Łk 16, 1), Samarytanki, proroka Jonasza, Rahab, niewidomego (J 9, 6), Aarona, Łazarza, Zuzanny, Marty, setnika, dobrego łotra, niewiasty (Mt 9, 20), Kananejki (Mt 15, 21), jawnogrzesznicy, Abla, Nikodema, 10 panien, paralityka z Kafarnaum, Marii Magdaleny, ubogiej wdowy, córki Jaira, 
Bartymeusza, bogacza (Łk 16, 14). Powyższe listy stanowią swoisty komentarz do wybranych tekstów biblijnych, często odwołujący się do tradycji, apokryfów, a także literatury powszechnej. Mając na uwadze przekazy z chrześcijańskiej tradycji, Autor stara się przemawiać do swoich adresatów po imieniu. I tak mówi do: niewidomego - Sydon, setnika - Longin, dobrego łotra - Dismas/Dimas, kobiety z drogi krzyżowej - Weronika, córki Jaira - Renata (wł. rinata - tzn. ponownie narodzona), lub Anastazja (dosł. powstała $z$ martwych). Niekiedy odwołuje się do języka greckiego i łacińskiego, aby ukazać etymologiczne znaczenie danego imienia (np. Longin). Ta wielość postaci biblijnych, z którymi pragnie spotkać się w raju, wskazuje jednocześnie na umiłowanie i znajomość Pisma Świętego. Komentując postać biblijną ze Starego Testamentu, Autor często odnosi się do tekstów nowotestamentalnych, przez co zaskakuje czytelnika oryginalnością skojarzeń. W przypadku Abla, mając na uwadze słowa Jezusa „Jeśli brat twój ma coś przeciw tobie..." (Mt 5, 23), stawia pytanie: dlaczego przed złożeniem ofiary nie poszedł wcześniej do swojego brata Kaina?

Dużo miejsca w swoim dziele Autor poświęcił świętym (20 listów), znanym $\mathrm{mu} z$ : historii powszechnej, regionalnej oraz związanym $\mathrm{z}$ jego osobą. I tak, czytając książkę spotykamy takich domowników nieba jak: św. Antonino Pierozzi, św. Mikołaj z Bari/Miry, św. Maria Goretti, św. Józef, św. Paulin z Noli, św. Tomasz More, św. Jan Fisher, św. Filip Neri, św. Szymon Słupnik, św. Joachim i Anna, św. Cleli Barbieri, św. Augustyn, św. Geominian, św. Omobono, św. Jan Chryzostom, św. Jan Vianney, św. Teresa od Dzieciątka Jezus, św. Franciszek, św. Aleksy, św. Grzegorz z Nazjanzu. To grono adresatów i całe dzieło zamyka list do Wszystkich Świętych, którzy stanowią nie tyle niezliczony tłum, ile raczej wspólnotę (comunione). Czytelnika zaskakuje znajomość szczegółów historycznych, a także bliska więź duchowa $\mathrm{z}$ każdym wymienionych adresatów. Na przykład św. Antonino to nie tylko patron Autora, lecz także autor pierwszego dzieła z teologii moralnej, z którym spotkał się w seminarium. Święty Paulin z Noli (355-431) z kolei to patron dnia, w którym odprawił Mszę św. prymicyjną (22 czerwca 1947 r.) oraz prekursor wykorzystania dzwonów w liturgii kościelnej. Ksiądz Leonelli czuje się spadkobiercą historii lokalnej i widzi w niej świętych jako wychowawców kolejnych pokoleń. Dlatego też odwołuje się do patronów Modeny św. Geominiana (313-397) i św. Omobono (zm. 1197) i prosi ich, aby wstawili się za nim, kiedy zapuka do bram nieba.

Obok świętych adresatami listów są także aniołowie: Anioł Stróż i Anioł Judasza Iskarioty. Pierwszy z nich jawi się jako wierny przyjaciel, gotowy do pomocy, który wstawi się $\mathrm{w}$ godzinie śmierci. O drugim zaś wspomina $\mathrm{z}$ okazji rzekomego odkrycia Ewangelii wedtug Judasza, o której tak głośno mówiły środki społecznego przekazu. Pisze do niego, ponieważ jest przekonany, iż w ,skrzynce pocztowej" judaszowego anioła nie ma zapewne wiele korespondencji. Trudno 
coś w tym przypadku powiedzieć, ale - zdaniem Autora - dramatem Judasza była nie tyle zdrada, ile raczej desperacja.

Ksiądz Antonino Leonelli, pomny na swe powołanie i misję duszpasterską, nie zapomniał skierować słowa do Jezusa Chrystusa, którego nazwał Boskim Mistrzem. Jest zachwycony formą Jego przepowiadania, a zwłaszcza przypowieściami. Wcielenie Słowa i Jego rola w dziele zbawienia zachęcają do doceniania wartości słowa w naszym życiu. Kolejnym adresatem omawianego dzieła jest Najświętsza Maryja Panna. W jej ziemskim życiu ks. Leonelli wyróżnił dwie nowenny, przeżyte w duchu modlitwy, kontemplacji i otwartości na Boże Słowo. Pierwsza z nich, która trwała dziewięć miesięcy i poprzedziła narodziny Bożego Syna. Zdaniem Autora oczekiwanie na narodziny stało sie dzisiaj w wielu wypadkach kwestią medyczną, czasem wypełnionym badaniami i wizytami u lekarza. Druga nowenna to dziewięć dni oczekiwania na zstąpienie Ducha świętego, jakie upłynęły od Wniebowstąpienia Pana Jezusa.

Wiele cennych informacji przynoszą pozostałe listy skierowane do postaci związanych z dniem dzisiejszym, a także z historią kościelną i powszechną. W tej grupie znaleźli się: siostra Łucja z Coimbry (Portugalia) - jedna z grupy dzieci fatimskich; ks. Seweryn Fabrani (1792-1849) - założyciel Instytutu dla Głuchoniemych w Modenie, o. Wincenty McNabb - autor książki Speranza buona, która dla Autora była drogowskazem w pierwszych latach kapłaństwa, ks. Ludwik A. Muratori - proboszcz parafii Pomposa, Guido G. Bruges (1830-1899) - poeta, ks. Fryderyk G. Faber - autor Konferencji duchowych, które stanowily pierwszą lekturę w czasach seminaryjnych, angielski pisarz Gilbert Kerit Chesterton (1874-1936), autor powieści Le avventure di un uomo viovo (ang. Manalive), która dla Autora stała się odskocznią podczas bombardowania latem 1944 roku, Elisa Totti - poetka i koleżanka z lat szkolnych, ks. Giambattista Cavazzuti (1750-1799) - „święty bez świec”, którego proces kanonizacyjny czeka na otwarcie, prof. Contardo Ferrini - wykładowca Uniwersytecki w Modenie (1891-1894), a także ks. kan. Sergiusz Ronchetti - penitencjarz kapituły katedralnej w Modenie. Wśród tych adresatów znaleźli się również papieże: Klemens XI - autor modlitw kapłańskich, Jan Paweł II, którego życie ks. Leonelli określa w skrócie „wiatrem Wojtyły”, Sylwester (zm. 335) - pierwszy święty nie męczennik w historii Kościoła katolickiego.

Patrząc na książkę ks. Antonino Leonelli od strony formalnej, należy podkreślić jej piękny język, styl i żywą, pogodną narrację. Podczas lektury dzieła dostrzegamy dużą znajomość dzieł patrologicznych oraz literatury teologicznej i świeckiej, tak współczesnej jak też przedwojennej. Warto też zaznaczyć, że dużym ułatwieniem w zrozumieniu różnych aluzji i dygresji językowych są słowa pisane kursywą. Autor zachwyca wprost znajomością terminologii i stylistyki łacińskiej, a także terminologii greckiej, która - jak pokazuje - leży u podstaw współczesnych pojęć języka włoskiego. Wielką kulturę ducha i znajomość hi- 
storii powszechnej oraz lokalnej potwierdza fabuła i kompozycja listów, które poruszają różnorodną tematykę, Co więcej, Autor z wielką łatwością porusza się w czasach biblijnych, a także w opoce pierwotnego chrześcijaństwa - aż po dzień dzisiejszy. Wydaje się, że pewnym przeoczeniem Autora (przyznał się do tego w prywatnej rozmowie) jest brak logicznego usystematyzowania zamieszczonych listów. Można było je ułożyć chronologicznie (data pisania, lub okres życia danego bohatera), bądź też tematycznie, co próbował uczynić recenzent. Taka systematyzacja ułatwiłaby lekturę i ukazałby z dodatkowo zamysł kompozycyjny Autora.

Podsumowując, należy stwierdzić, iż ks. Antonino Leonelli w książce Fermo posta. Paradiso jawi się jako kapłan, intelektualista, pedagog i duszpasterz. Jak zawsze jest on zatroskany nie tylko o swój los, lecz również o życie wszystkich ludzi, bliskich jego sercu oraz czytelników, z którymi pragnie uwielbiać Boga według słów Psalmisty: „Caeli enarrant gloriam Dei” (Ps. 18, 2). Dlatego też warto przeczytać jego ostatnie dzieło, które od roku jest dostępne na włoskim rynku księgarskim. 